The role of political attention in moderating the association between political identities and anthropogenic climate change belief in Britain

\author{
John Kenny \\ Department of Politics and International Relations, \\ University of Southampton \\ Email: j.p.kenny@ soton.ac.uk \\ ORCID: https://orcid.org/0000-0001-9401-3555
}

This paper has been published in Political Studies. The Version of Record can be found at the following link: https://doi.org/10.1177/0032321720928261 


\section{The role of political attention in moderating the impact of political identities on anthropogenic climate change belief in Britain}

\section{Abstract}

US research shows that the partisan divide among elites on climate change has been mirrored by division at the citizen level, with this division being especially prominent among more politically engaged citizens. Using British Election Study data from 2016, this paper examines whether a similar phenomenon is occurring in Britain, a country that experienced an increase in climate sceptic media coverage in the aftermath of the passing of the 2008 Climate Change Act. The results show that UK Independence Party and Conservative Party partisans as well as Leavers that pay more attention to politics are less likely to believe in the existence of anthropogenic climate change in contrast to Labour Party partisans and Remainers where increased political attention is associated with greater belief. These findings point to the inherent difficulties of bringing public beliefs on climate change in line with the scientific consensus in the presence of divided elite cues.

Keywords: Britain, beliefs, climate change, elite cues, partisanship.

\section{Introduction}

This paper examines anthropogenic climate change belief in Britain with a particular focus on the moderating role of political attention. The scientific evidence for the occurrence of anthropogenic climate change has continued to become more and more certain. The Intergovernmental Panel on Climate Change has found that, 'It is extremely likely that human activities caused more than half of the observed increase in global average surface temperatures from 1951 to 2010' (Stocker et al., 2013: 60). With the negative consequences of continued global warming resulting from human activity including the loss of biodiversity, rising sea-levels and more extreme droughts and heatwaves, the scientific community recommends that action to mitigate against such occurrences is taken urgently.

When it comes to implementing such policies, government action has lagged behind. As Remnick (2015: 36) remarks, 'The awareness of nearly all of the world's leaders of the imminence of devastating climate change has roused almost none of them to effective action'. While debate rages on the adequacy of national emissions reductions pledges made at the 2015 Climate Change Summit in Paris, countries are not on track to meet even these selfimposed targets (Plumer and Popovich, 2018; United Nations Environment Programme, 2017). This includes the UK where the Committee on Climate Change (2019) noted in their 
annual report of July 2019 that the country only delivered 1 of their 25 critical policies needed to reach their emissions reduction targets during the previous 12 months.

An important reason for this foot-dragging has been that the issue has not reached the top of the public agenda. YouGov $(2015,2020)$ surveys from 2010 to the autumn of 2018 reveal that - apart from a brief rise during the floods of February 2014 that dissipated almost immediately afterwards - environmental issues in general were only mentioned as one of the three top issues facing the country by approximately 1 in every 10 people. This has risen notably since in tandem with the Extinction Rebellion protests, though, as of February 2020, it is still named as one of three top issues by fewer than 3 in every 10 people. And when individuals are asked to choose just one issue, Ipsos MORI (2020) polling from December 2019 reveals that environmental issues are mentioned by just 1 in every 20 people. Political parties and governments tend to prioritise the issues that are most important to the electorate given that, with limited time and resources, this strategy may most efficiently increase their prospects at the next election (Anderson et al., 2017: 3). Thus, all else being equal, they are unlikely to implement climate change policies in the absence of widespread societal pressure.

Moving one step further back along the chain, what makes this particularly difficult to remedy is that the public do not universally accept the scientific consensus. In Britain, surveys from both 2014 and late 2016/early 2017 show that only $37 \%$ and $36 \%$ of the population respectively believe that climate change is caused either mainly or entirely by human activity (Capstick et al., 2015; Fisher et al., 2018). In other surveys from late 2015 and the first half of 2016 where individuals did not have to assign a degree of human responsibility for climate change, approximately $60 \%$ of respondents thought that humans had some responsibility for climate change (Kenny, 2018, 2020). While believing in humans' contribution to climate change does not automatically equate with supporting mitigation measures - as has been shown in a British study examining the relationship between belief in 
anthropogenic climate change and support for a net-zero emissions target by 2050 (Fisher, 2019) - individuals who do not believe in anthropogenic climate change are much less likely to prioritise action on climate change (Krosnick et al., 2006; Van Der Linden et al., 2015) given that they either believe it is due to natural factors or even that it is not occurring at all. Thus, the disjunction between the scientific consensus and public belief is likely playing an intermediary role in holding back progress on implementing the climate change policies that are required to limit increases in global surface temperature.

In this paper, I examine the correlates of belief in anthropogenic climate change in Britain. Firstly, I test whether the demographic factors that are most-associated with climate change belief in the literature remain significant or are explained away once political identities, values and trust in experts are accounted for. I find that - though reduced in size most of these demographics continue to have significant effects on climate change belief even when other factors are controlled for. On the effects of the values themselves, I show that individuals who have more leftist values, who are against traditional gender roles and who are supportive same-sex marriage are more likely to believe in anthropogenic climate change. The positive effect of libertarian-authoritarian values capturing obedience, patriotism and respect for authority however fails to hold once the positive effect of those who place more trust in experts than ordinary people is accounted for. Political identities are associated with people's climate change beliefs as has been demonstrated previously for partisanship (Carter and Clements, 2015) as well as for how one voted in the 2016 EU referendum (Fisher et al., 2018), but what this paper demonstrates for the first time in Britain is that such identities interact with political attention in their relationship with climate change beliefs. For Labour partisans, greater political attention is associated with greater belief in anthropogenic climate change, whereas for Conservative and UK Independence (UKIP) partisans greater political attention is associated with lower belief. And while there is no significant difference 
between Remainers and Leavers in their climate change beliefs at the lowest levels of political attention, a gap opens with increased political attention whereby Remainers are more likely to believe in anthropogenic climate change and Leavers less likely to do so. This all ties in with the diverging elite cues that such individuals are receiving on the subject and suggests - like has been occurring in the US (Brulle et al., 2012) - that elites play a substantial role in shaping individuals' climate change beliefs.

\section{Literature:}

Much is already known about the factors that shape climate change beliefs, both in Britain and in general. In this section, I begin by presenting the socio-demographic factors most commonly associated with climate change belief. I then review the literature on what we do and do not know about the association between climate change belief and political values as well as (dis)trust in experts. This is followed by analysis of the role of political identities, political cues and information sources in influencing climate change beliefs.

There are a number of socio-demographic factors that have been shown to correlate with climate change belief in Britain. In particular, higher levels of climate scepticism have been found amongst older individuals, men, the lower educated, the working class and those living in rural areas (Clements, 2012; Fisher et al., 2018; Poortinga et al., 2011; Whitmarsh, 2011). Additionally, belief in anthropogenic climate change tends to be higher in London than other regions (ComRes, 2017; Pearce, 2015).

Though each of these demographic characteristics may have specific mechanisms through which they affect climate change beliefs (see Poortinga et al., 2019: 25/26), a potential overall explanation may be due to their association with libertarian-authoritarian values. While libertarian values place an emphasis on equality, freedom and selfassertiveness, authoritarian values are focused on obedience, patriotism and respecting authority. Individuals with authoritarian values share the same demographic characteristics as 
listed for climate sceptics above, with lower education and being older being particularly powerful predictors, and also express lower concern and support for the environment (Flanagan and Lee, 2003). While environmental values have been shown to tap into a different dimension - both theoretically and empirically - than libertarian-authoritarian values (Kenny, 2020; Knutsen, 2017: 14), the effect of libertarian-authoritarian values on climate change beliefs has been much less explored than their effect on general environmental attitudes. Of particular interest in this paper is whether such values can explain away the significance of demographic characteristics.

H1 Individuals with libertarian values are more likely to believe in anthropogenic climate change than individuals with authoritarian values

What is also important for believing in humans' contribution to climate change is that individuals trust the information that is conveyed by climate scientists (Pidgeon and Fischhoff, 2011). Evidence from the US suggests that the Climategate scandal eroded some of this trust at the beginning of the last decade and may have been responsible for at least some of the increase in climate scepticism that occurred at that time (Leiserowitz et al., 2013). The US has also been notable for the efforts by the conservative movement there to erode trust in climate scientists by undermining their scientific legitimacy, with some evidence of elements of the US conservative movement's environmental scepticism having spread to the UK (McCright and Dunlap, 2010). However, such effects of (dis)trust may extend beyond just climate scientists but also to those disseminating the message and implementing relevant policy, with Fairbrother (2017: 2) noting that a distinctive factor that brings together those sceptical of environmental science is 'their alienated, resentful distrust of virtually all elite social institutions, including communities of experts'. Despite the theoretical reasons for believing that trust in experts is important, its relationship with anthropogenic climate change is not commonly modelled, though a recent article has relatedly shown that British individuals with populist attitudes are more climate sceptic 
(Huber, 2020). It is particularly noteworthy that those who distrust experts are prevalent among older generations, people living in rural areas and the less educated (Fairbrother, 2017: 5), thus sharing many of the same demographic characteristics as climate sceptics as outlined above and indeed those with authoritarian values. Controlling for these demographic factors, might we see an effect of trust in experts on climate change beliefs? Or does trust in experts explain away the effects of some of the demographic factors?

$\mathrm{H} 2$ Individuals that trust experts are more likely to believe in anthropogenic climate change than those that distrust experts

It is also the case that political dispositions play a role in individuals' climate change beliefs. Research from psychology has shown a congruence between conservative political beliefs and a desire to avoid uncertainty or to protect a threatened system; given a motivation to rationalise the status quo, even those who are disadvantaged by a particular system may be motivated to protect it (Jost et al., 2003; Jost and Hunyady, 2005). As right-leaning, conservative individuals are more wedded to the existing economic system that is threatened both by climate change itself and by efforts to tackle climate change, they are more likely to engage in motivated reasoning to challenge climate science and reduce their own dissonance (Santos and Feygina, 2017). The left-right ideological divide in climate change beliefs has been demonstrated in Western Europe (Dunlap et al., 2016; Poortinga et al., 2019) as well as the United States (McCright and Dunlap, 2011).

H3 Left-leaning individuals are more likely to believe in anthropogenic climate change than right-leaning individuals.

A divide can also be seen in Britain when one disaggregates climate change beliefs by political party support. YouGov data from 2008 to 2014 shows that UKIP supporters are by far the most likely to report that climate change is not a result of human activity/not happening followed by Conservative supporters, while Labour and to a greater extent Liberal 
Democrat supporters are less likely to respond in this way (Carter and Clements, 2015: 218) ${ }^{1}$. That UKIP supporters show the lowest levels of belief in anthropogenic climate change matches their status as a populist-right party, with a key reason for why supporters of populist-right parties may be particularly climate sceptic being that such parties possess an ideological content that 'combines authoritarian and nationalistic values with anti-elitism, producing hostility to climate change as a cosmopolitan elite agenda, along with a suspicion of both the complexity of climate science and policy and of the role of climate scientists and environmentalists' (Lockwood, 2018: 703). UKIP's framing of climate change matches this status where their tweets frequently criticise the integrity of the International Panel on Climate Change describing the panel's work as 'bogus', 'doctored' and 'dodgy' - and thus attempting to discredit the scientific basis for anthropogenic climate change - as well as retweeting posts by climate sceptic think tanks and posting links themselves to climatesceptic articles on other websites (Reed, 2016).

The high levels of scepticism seen amongst Conservative supporters also match cues sent out by a substantial proportion of climate-sceptic right-wing Conservative MPs especially since the passing of the 2008 Climate Change Act - who framed climate change policies in the media through traditional conservative frames such as an unwarranted state intervention, unnecessary green taxes and as being associated with the EU (Lockwood, 2013: 1344). While it must be noted that Conservative MPs who deny climate change outright are relatively small ${ }^{2}$, 'a much wider group of [Conservative] MPs has been willing to embrace a critical discourse on climate policy, for a combination of ideological and pragmatic reasons' (Carter and Clements, 2015: 217). Despite David Cameron advocating 'Vote Blue, Go Green' while leader of the opposition - a strategy which pressured the then Labour

\footnotetext{
${ }^{1}$ Figures for Green Party supporters are not reported

${ }^{2}$ In this respect, this is a key difference with the much starker partisan elite divides in the US where, for instance, the Senate split 50-49 in a January 2015 vote on an amendment on whether the Senate would affirm climate change's anthropogenic cause (Jasny et al., 2015: 783).
} 
government into implementing a number of climate policies when the climate was arguably seen as a valence issue (Carter, 2009) - and declaring that the coalition government would be the 'greenest government ever', as prime minister he dropped such cues given the division within the parliamentary party on the issue at a time when serious economic difficulties dominated (Carter and Clements, 2015). These divisions had started to show clearly approximately 18 months into the coalition government around the time that the then Chancellor of the Exchequer George Osbourne let his view be known at the annual party conference that 'we're not going to save the planet by putting our country out of business'. By doing so, this provided dissatisfied backbenchers with a figure at the heart of government who could voice their concerns as well as lobby against key climate policies (Carter, 2014). Some of the optics of deprioritising climate change were initially continued upon Theresa May becoming Prime Minister in 2016 when she immediately abolished the Department for Energy and Climate Change (Innes, 2019). Thus, at the mid-point of the decade, it could be concluded that 'since 2010 climate change has become a positional issue in British politics, with large sections of the Conservative Party, UKIP and their supporters in the wider electorate, holding sceptical views on climate change and opposing government action to address it' (Carter and Clements, 2015: 222). .

H4 Individuals with a Conservative or UKIP identity are less likely to believe in anthropogenic climate change than those that identify with other parties.

This above-mentioned linking of climate change with the EU is particularly important in light of Brexit. We know that there is a correlation between individuals' belief in anthropogenic climate change and their vote in the Brexit referendum. European Social Survey data from late 2016/early 2017 shows that while 71 per cent of remain voters believe that climate change is definitely happening, among leave voters this drops to 53 per cent (Fisher et al., 2018: 164). As 92 per cent of middle-class liberals voted for remain (Swales, 2016: 25) - a group that also shows high levels of concern for the environment and climate 
change - this correlation is understandable. However, Brexit vote patterns have also turned into notable identities for individuals that affect how they interpret political information and have shown remarkable stability (Hobolt et al., 2020; Hobolt and Tilley, 2019). Do Brexit identities help explain belief in anthropogenic climate change beyond other known social and political predictors? With leave voters having an inward-looking world view (Bevington, 2018), this would tie in with previous work linking climate change views to cosmopolitanism (Caney, 2010) which, at its core, captures being open to others from around the world and having a sense of obligation towards them (Martell, 2017). Research from Australia has empirically demonstrated that individuals that have stronger global than national attachments are more likely to believe in anthropogenic climate change in contrast to those with stronger national than global attachments (Devine-Wright et al., 2015). Thus, with the inward-looking perspective of Leavers contrasting to the outward-looking perspective of Remainers and these views gaining validity through being cemented in the respective identities, it is hypothesised that individuals' referendum identity could help to explain their belief in anthropogenic climate change beyond that which is explained through other factors.

H5 Individuals who identify as Remainers are more likely to believe in anthropogenic climate change than those that identity as Leavers.

There are also reasons to believe that the association between individuals' political identities and their belief in anthropogenic climate change may be moderated by the attention they pay to politics. Evidence from the US suggests that the party elite cues that are transmitted through the mass media are important for explaining the gap in climate change beliefs between Republican and Democrat partisans, with cues from Republican politicians in the media - who themselves have been influenced by organised campaigns from lobby groups promoting misinformation on climate change (Brulle and Roberts, 2017) - having become increasingly climate sceptic in stark contrast to the almost universal stances from Democrat partisans in support of the scientific consensus (Merkley and Stecula, 2018). 
Individuals who pay greater attention to politics are more likely to be exposed to such arguments and pay attention to them. Indeed, while higher levels of interest in politics, education, self-reported understanding of the issue and attention to political news are associated with lower levels of climate-scepticism for liberals/Democratic partisans, they are associated with either no change or increased climate scepticism for conservatives/Republican partisans (McCright and Dunlap, 2011; Tesler, 2018). If individuals are receiving their information in these echo chambers, they may also be more likely to devalue alternative information coming from across the partisan divide should they come into contact with it (Merkley and Stecula, 2018). And experimental research shows that even when high-knowledge Republicans' perceptions of the presence of a scientificconsensus increase, this does not translate to an increased personal belief in anthropogenic climate change (Bolsen and Druckman, 2018). Thus, correcting such perceptions - especially after they have been politicised - can be extremely difficult to achieve (Flynn et al., 2017).

In light of the affective polarisation in British politics between partisans of the left and the right as well as the more recent polarisation between Remainers and Leavers (Hobolt et al., forthcoming), might we be witnessing a similar phenomenon here in the relationship between political attention and anthropogenic climate change belief? This is especially pertinent as we already know that there is a correlation between both party and referendum identities and beliefs in climate change as discussed above, and this tests a further mechanism through which these divisions could be developing.

H6a Those with a Conservative or UKIP identity who pay more attention to politics are less likely to believe in anthropogenic climate change.

H6b Those with a Labour, Liberal Democrat, Green or Scottish National Party (SNP) identity who pay more attention to politics are more likely to believe in anthropogenic climate change.

H7a Those with a Leave identity who pay more attention to politics are less likely to believe in anthropogenic climate change. 
H7b Those with a Remain identity who pay more attention to politics are more likely to believe in anthropogenic climate change.

Finally, this is further compounded by the way in the which the British press cover the issue. Left-wing/anti-Brexit newspapers tend to disseminate information in line with the scientific consensus whereas right-wing/pro-Brexit newspapers tend to contain more sceptical messages. Carrying out content analysis of British national newspapers, Painter and Gavin (2016) show that from early 2007 to late 2009/early 2010, the coverage given to climate sceptics increased dramatically to previously unseen levels. Moreover, the right-leaning newspapers of the Express, the Telegraph and the Sun were much more willing to publish uncontested climate sceptic opinion pieces and editorials than the left-leaning Independent, Guardian and Mirror. And many of these uncontested climate sceptic pieces were written by Conservative Party politicians. A House of Commons Science and Technology Committee (2014: 20-22) report echoes Painter and Gavin's conclusions. It found that the Guardian reported responsibly on the issue, though it was particularly critical of the Mail and the Telegraph with the former noting in their written submission that they consider climate science to be a political issue and the latter noting that their sole responsibility was to produce content that their readers were happy to pay for:

We are very disappointed by the heavy reliance that the Daily Mail and the Daily Telegraph place on the ability of their readers to distinguish fact and opinion on climate science. This is especially the case because opinion pieces about climate science in these publications are frequently based on factual inaccuracies which go unchallenged.

While one would of course expect self-selection into readership of these sources and that people who read these may already be sceptical of the scientific facts, a panel study in the US demonstrates that the consumption of conservative media decreases trust in scientists and as a result people's certainty that global warming is happening while consumption of non- 
conservative media has the opposite effect $^{3}$ (Hmielowski et al., 2013). Thus, the differing cues that individuals receive through these different news-sources may also be playing a role in cementing the divide in belief in anthropogenic climate change.

H8 Those who read newspapers that devote greater coverage to climate sceptic arguments are less likely to believe in anthropogenic climate change than those who read newspaper whose coverage aligns more with the scientific consensus.

\section{Data}

For my analysis, I use wave 10 of the British Election Study (BES) internet panel data (Fieldhouse et al., 2016). This was fielded online through YouGov from $24^{\text {th }}$ November $12^{\text {th }}$ December 2016 and has a sample size of 30,237 individuals.

Wave 10 is the only wave of the BES to date where an anthropogenic climate change belief question has been asked to all respondents. It additionally contains the range of other demographic, identity, values and information variables that are necessary for this analysis. The large sample size is beneficial as it allows enough power to test the interaction between political attention and less-widespread partisan identities - such as Green party partisanship that would be unfeasible with regular-sized samples. The timing is particularly suitable given that it occurred in the aftermath of the Brexit referendum - allowing for the association Brexit identities with climate change belief to be tested - and the preceding years had witnessed a sufficient divergence in elite cues on the issue to allow for the possibility that the public may have followed suit.

\section{Dependent Variable:}

The dependent variable asks respondents, 'On the subject of climate change do you think ...': 'The world's climate is changing due to human activity'; 'The world's climate is changing but not due to human activity'; 'The world's climate is not changing'; 'Don't

\footnotetext{
${ }^{3}$ In their study, conservative media consisted of frequency of consuming Fox News and The Rush Limbaugh Show, while non-conservative media consisted of CNN, MSNBC, National Public Radio and network news.
} 
Know'. This question provides respondents with options expressing agreement with the scientific consensus, scepticism of humans' contribution towards it and outright denial that it is occurring.

\section{Independent Variables:}

Demographics:

The demographic variables that I include are highest educational attainment (none;

GCSE or less; A-Level; undergraduate degree; other technical, professional or higher qualification; postgraduate degree; don't know/prefer not to say), age, gender, household income $(<£ 15,000 ; £ 15,000-£ 29,999 ; £ 30,000-£ 44,999 ; £ 45,000-69,999 ;>£ 70,000$; Prefer not to answer; don't know) and region (North East, North West, Yorkshire and the Humber; East Midlands; West Midlands; East; South East; London; South West; Wales; Scotland).

\section{Identities:}

The first identity I use is partisanship. This is captured by a question asking respondents 'Generally speaking, do you think of yourself as Labour, Conservative, Liberal Democrat or what?'. Where respondents answered don't know or none, I have merged responses with those to the subsequent question, 'Do you generally think of yourself as a little closer to one of the parties than the others? If yes, which party?'. Response categories have been coded into none, Conservative, Labour, Liberal Democrat, SNP, UKIP, Green, other, and don't know.

Secondly, as a measure of EU referendum identity, I use the following question, 'In the EU referendum debate, do you think of yourself as closer to either the 'Leave' or 'Remain' side? If yes, which one?' with response categories of the remain side, the leave side, neither and don't know. Furthermore, to capture individuals' sense of European national identity beyond solely their EU referendum identity, I use a scale that asks respondents to 
self-place themselves between 1 (Not at all) to 7 (Very strongly) regarding their sense of their Europeanness ${ }^{4}$.

\section{Values and Trust:}

To capture left-right values, I use an index composed of agreement with the following items on a 5-point scale: 'Government should redistribute income from the better off to those who are less well off', 'Big business takes advantage of ordinary people', 'Ordinary working people do not get their fair share of the nation's wealth', 'There is one law for the rich and one for the poor' and 'Management will always try to get the better of employees if it gets the chance'. I have coded this so that 1 represents right values and 5 left values.

To capture libertarian-authoritarian values relating to obedience, patriotism and respecting authority, I use an index composed of agreement with the following items on a 5point scale: 'Young people don't have enough respect for traditional British values', 'For some crimes, the death penalty is the most appropriate sentence', 'Schools should teach children to obey authority', 'Censorship of films and magazines is necessary to uphold moral standards' and 'People who break the law should be given stiffer sentences'. This is coded so that 1 represents authoritarian values and 5 represents libertarian values.

In addition, to capture values surrounding equality, I utilise the following two questions which are asked on a five-point scale from strongly disagree to strongly agree: 'Gay or lesbian couples should have the right to marry one another if they want' and 'A man's job is to earn money, a woman's job is to look after the home and family'. In each case, 1 represents inequality and 5 equality values.

Finally, to capture trust in experts and the holding of anti-intellectual values, I use the following question that was also asked on a five-point scale from strongly disagree to

\footnotetext{
${ }^{4}$ Individuals who responded 'Don't Know' on this scale (782) have been treated as missing in the regression analyses
} 
strongly agree 'I'd rather put my trust in the wisdom of ordinary people than the opinions of experts'.

For all of the questions in this section, those who answered 'don't know' have been treated as missing. ${ }^{5}$

\section{Information:}

For information, I make use of two variables. The first is 'How much attention do you generally pay to politics?' which is measured on a 0-10 scale ${ }^{6}$. I next use the daily newspaper that individuals read most often (None; The Express; The Daily Mail; The Mirror/Daily Record; The Daily Star; The Sun; The Daily Telegraph; The Financial Times; The Guardian; The Independent; The Times; Other). Thus, I can approximate both individuals' level of political engagement as well as the source of their news.

\section{Results}

To begin with, in Figure 1 I present the distribution of responses to the climate change belief question. This shows that $62 \%$ of individuals believe that climate change is occurring due to human activity, $18 \%$ believe climate change is occurring but not due to human activity, $5 \%$ do not believe that the climate is changing at all and $16 \%$ don't know. Thus, the ratio of stating a belief in human-caused climate change to not stating one is approximately $3: 2$.

\footnotetext{
5 3,854 for left-right values index, 4,134 for the libertarian-authoritarian values index, 1,020 for support for same sex marriage, 563 for agreement with traditional gender roles and 1,410 for trust in experts,

${ }^{6}$ Individuals who responded 'Don't Know' on this scale (340) have been treated as missing in the regression analyses.
} 
Figure 1: Belief in Climate Change

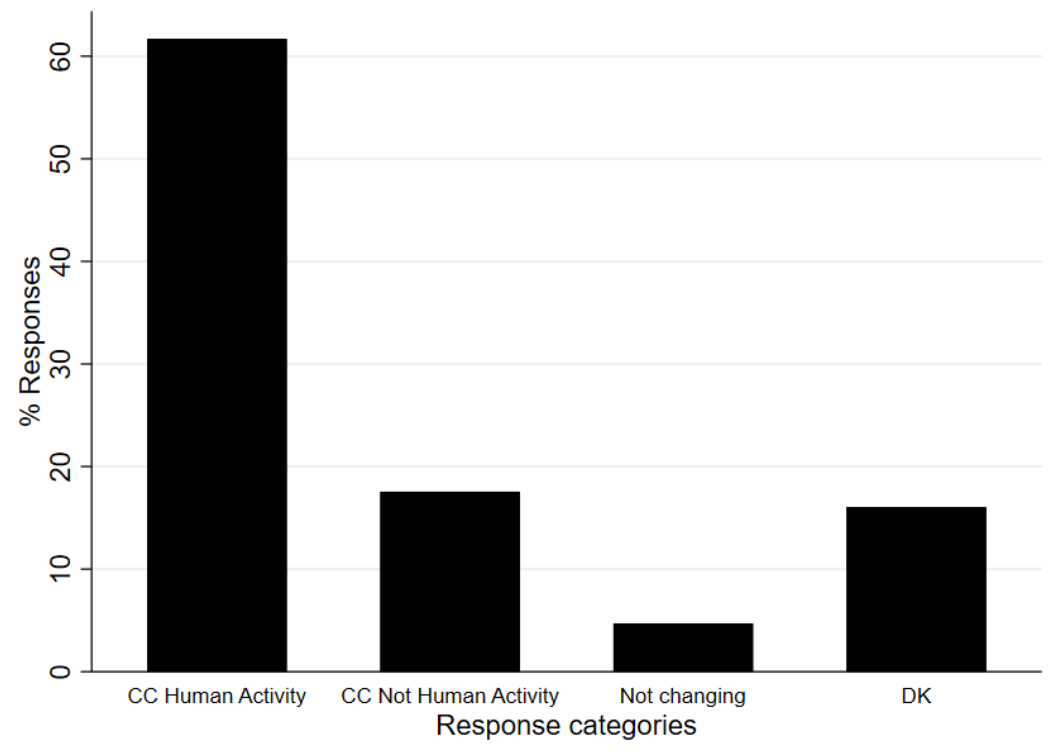

Given the distribution of these responses and the interest of the article being on explaining whether individuals believe in anthropogenic climate change or not, in my analysis I dichotomize this as 1 if respondents state that they believe in anthropogenic climate change and 0 if they do not thus combining the three other responses ${ }^{7}$.

In Table 1, I present the results from logistic regression analyses in which I gradually build up my model. The first model contains just the demographic variables, the second adds in the identity variables, the third includes the values variables, the fourth adds trust in experts and finally the fifth has the information variables.

\section{Demographics:}

Firstly, I examine the demographic variables. In the first model, they all behave as expected. Individuals who have higher educational achievements, who are younger, who are female and who have higher household incomes are all more likely on average to believe in anthropogenic climate change. Region-wise, belief is highest in London and lowest in the North and the Midlands.

When the identities variables are added to model 2 , there is a notable dampening of the age, household income and especially education effects. The regional effects in the

\footnotetext{
${ }^{7}$ In the robustness section, I also report results for when all of these categories are kept separate.
} 
Midlands and the South are completely explained away. In contrast, the effect of gender in the model remains virtually unchanged. The pseudo- $\mathrm{R}^{2}$ increases sizeably in this model from .04 to .11 .

The third model sees the introduction of the values variables. The most striking thing here is that - while still significant - this almost halves the magnitude of the gender coefficient while also further eroding the effects of education and age. The pseudo- $\mathrm{R}^{2}$ increases by 0.03 . The addition of trust in experts in model 4 further reduces the coefficients for age and education, and the addition of the information variables in model 5 removes the significance of having an undergraduate education, though not of having a postgraduate degree.

Table 1: Belief in anthropogenic climate change logistic regression

\begin{tabular}{|c|c|c|c|c|c|c|c|c|c|c|}
\hline \multirow[b]{2}{*}{ VARIABLES } & \multicolumn{2}{|c|}{ Demographics } & \multicolumn{2}{|c|}{ Identities } & \multicolumn{2}{|c|}{ Values } & \multicolumn{2}{|c|}{ Trust } & \multicolumn{2}{|c|}{ Information } \\
\hline & coef & se & coef & se & coef & $\mathrm{Se}$ & coef & se & coef & $\mathrm{Se}$ \\
\hline \multicolumn{11}{|l|}{ Education (None) } \\
\hline GCSE & 0.08 & $(0.07)$ & 0.01 & $(0.07)$ & -0.01 & $(0.08)$ & -0.00 & $(0.08)$ & -0.00 & $(0.08)$ \\
\hline A-Level & $0.44 * * *$ & $(0.07)$ & $0.21 * *$ & $(0.08)$ & $0.18 *$ & $(0.08)$ & 0.15 & $(0.08)$ & 0.15 & $(0.08)$ \\
\hline Undergraduate & $0.68^{* * *}$ & $(0.07)$ & $0.27 * * *$ & $(0.08)$ & $0.24 * *$ & $(0.08)$ & $0.18^{*}$ & $(0.08)$ & 0.15 & $(0.08)$ \\
\hline $\begin{array}{l}\text { Other technical, professional or } \\
\text { higher }\end{array}$ & $0.38 * * *$ & $(0.08)$ & 0.14 & $(0.08)$ & 0.12 & $(0.08)$ & 0.09 & $(0.08)$ & 0.07 & $(0.09)$ \\
\hline Postgraduate & $1.07 * * *$ & $(0.09)$ & $0.52 * * *$ & $(0.10)$ & $0.45^{* * *}$ & $(0.10)$ & $0.34 * *$ & $(0.10)$ & $0.29 * *$ & $(0.10)$ \\
\hline DK/Prefer not to say & -0.15 & $(0.13)$ & -0.26 & $(0.14)$ & -0.19 & $(0.14)$ & -0.20 & $(0.14)$ & -0.22 & $(0.14)$ \\
\hline Age (10 years) & $-0.15 * * *$ & $(0.01)$ & $-0.10 * * *$ & $(0.01)$ & $-0.08 * * *$ & $(0.01)$ & $-0.06 * * *$ & $(0.01)$ & $-0.06 * * *$ & $(0.01)$ \\
\hline Female & $0.22 * * *$ & $(0.03)$ & $0.21 * * *$ & $(0.04)$ & $0.13 * * *$ & $(0.04)$ & $0.13^{* * *}$ & $(0.04)$ & $0.13 * * *$ & $(0.04)$ \\
\hline \multicolumn{11}{|l|}{ Household Income $(<£ 15,000)$} \\
\hline$£ 15,000-£ 29,999$ & -0.04 & $(0.06)$ & -0.05 & $(0.06)$ & -0.03 & $(0.06)$ & -0.04 & $(0.06)$ & -0.02 & $(0.06)$ \\
\hline$£ 30,000-£ 44,999$ & 0.02 & $(0.06)$ & 0.01 & $(0.07)$ & 0.03 & $(0.07)$ & 0.02 & $(0.07)$ & 0.04 & $(0.07)$ \\
\hline$£ 45,000-£ 69,999$ & $0.21 * *$ & $(0.07)$ & $0.17^{*}$ & $(0.07)$ & $0.18^{*}$ & $(0.07)$ & $0.15^{*}$ & $(0.08)$ & $0.16^{*}$ & $(0.08)$ \\
\hline$>70,000$ & $0.26^{* *}$ & $(0.08)$ & $0.18^{*}$ & $(0.09)$ & $0.21 *$ & $(0.09)$ & 0.17 & $(0.09)$ & 0.16 & $(0.09)$ \\
\hline Prefer not to answer & -0.08 & $(0.06)$ & -0.00 & $(0.06)$ & 0.03 & $(0.06)$ & 0.03 & $(0.07)$ & 0.03 & $(0.07)$ \\
\hline DK & 0.10 & $(0.09)$ & 0.05 & $(0.10)$ & 0.06 & $(0.10)$ & 0.04 & $(0.10)$ & 0.04 & $(0.10)$ \\
\hline \multicolumn{11}{|l|}{ Region (London) } \\
\hline North East & $-0.27 * *$ & $(0.10)$ & -0.18 & $(0.11)$ & $-0.23 *$ & $(0.11)$ & $-0.25^{*}$ & $(0.11)$ & $-0.23^{*}$ & $(0.11)$ \\
\hline North West & $-0.34 * * *$ & $(0.08)$ & $-0.33 * * *$ & $(0.09)$ & $-0.34 * * *$ & $(0.09)$ & $-0.32 * * *$ & $(0.09)$ & $-0.30 * * *$ & $(0.09)$ \\
\hline Yorkshire and the Humber & $-0.30 * * *$ & $(0.08)$ & $-0.25^{* *}$ & $(0.09)$ & $-0.29 * *$ & $(0.09)$ & $-0.29 * *$ & $(0.09)$ & $-0.29 * *$ & $(0.09)$ \\
\hline East Midlands & $-0.31 * * *$ & $(0.09)$ & -0.17 & $(0.09)$ & $-0.20 *$ & $(0.09)$ & $-0.21 *$ & $(0.09)$ & $-0.19 *$ & $(0.09)$ \\
\hline West Midlands & $-0.25^{* *}$ & $(0.09)$ & -0.15 & $(0.09)$ & -0.13 & $(0.09)$ & -0.11 & $(0.09)$ & -0.09 & $(0.09)$ \\
\hline East of England & -0.13 & $(0.08)$ & 0.00 & $(0.09)$ & 0.01 & $(0.09)$ & 0.01 & $(0.09)$ & 0.03 & $(0.09)$ \\
\hline South East & $-0.21 * *$ & $(0.08)$ & -0.13 & $(0.08)$ & -0.14 & $(0.08)$ & -0.14 & $(0.08)$ & -0.10 & $(0.08)$ \\
\hline
\end{tabular}


South West

Wales

Scotland

Partisanship (None)

Conservative

Labour

Liberal Democrat

SNP

UKIP

Green

Other

DK

Referendum ID (Remain side)

Leave side

Neither

DK

Europeanness

Left-right scale

Libertairain-authoritarian scale

Support gay marriage

Oppose traditional gender roles

Rather trust wisdom of ordinary people than experts

Attention to politics

Newspaper Readership (None)

The Express

The Daily Mail

The Mirror/Daily Record

The Daily Star

The Sun

The Daily Telegraph

The Financial Times

The Guardian

The Independent

The Times

Other

\section{Constant}

Observations

Log Lik

Log Lik (Null)

Pseudo R-squared

$\begin{array}{ccccccccc}-0.21 * * & (0.08) & -0.15 & (0.09) & -0.13 & (0.09) & -0.12 & (0.09) & -0.11 \\ -0.11 & (0.09) & -0.05 & (0.10) & -0.05 & (0.10) & -0.05 & (0.10) & -0.04 \\ -0.15 & (0.08) & -0.35 * * * & (0.10) & -0.31 * * & (0.10) & -0.32 * * & (0.10) & -0.32 * *\end{array}$

(0.09)

$(0.10)$

(0.10)

$\begin{array}{lccccccccc}\ldots & \ldots & -0.17 * * & (0.06) & 0.04 & (0.06) & -0.04 & (0.06) & 0.03 & (0.07) \\ \ldots & \ldots & 0.30^{* * *} & (0.07) & 0.23 * * * & (0.07) & 0.19 * * & (0.07) & 0.18^{* *} & (0.07) \\ \ldots & \ldots & 0.53 * * * & (0.10) & 0.51 * * * & (0.10) & 0.43^{* * *} & (0.10) & 0.42^{* * *} & (0.10) \\ \ldots & \ldots & 0.39 * * & (0.13) & 0.23 & (0.13) & 0.26 & (0.13) & 0.28^{*} & (0.14) \\ \ldots & \ldots & -0.45^{* * *} & (0.08) & -0.33 * * * & (0.08) & -0.29 * * * & (0.08) & -0.25 * * & (0.08) \\ \ldots & \ldots & 1.48^{* * *} & (0.18) & 1.32 * * * & (0.18) & 1.28^{* * *} & (0.18) & 1.26 * * * & (0.18) \\ \ldots & \ldots & -0.00 & (0.17) & -0.08 & (0.17) & -0.09 & (0.17) & -0.10 & (0.18) \\ \ldots & \ldots & -0.31 * & (0.13) & -0.27 * & (0.13) & -0.28^{*} & (0.13) & -0.27 * & (0.13)\end{array}$

$\begin{array}{ccccccccccc}\ldots & \ldots & -0.81 * * * & (0.05) & -0.71 * * * & (0.05) & -0.57 * * * & (0.05) & -0.52 * * * & (0.05) \\ \ldots & \ldots & -1.06 * * * & (0.08) & -0.89 * * * & (0.08) & -0.79 * * * & (0.08) & -0.77 * * * & (0.08) \\ \ldots & \ldots & -1.41 * * * & (0.13) & -1.22 * * * & (0.13) & -1.12 * * * & (0.13) & -1.08 * * * & (0.14) \\ & & & & & & & & & & \\ \ldots & \ldots & 0.08 * * * & (0.01) & 0.07 * * * & (0.01) & 0.05 * * * & (0.01) & 0.05 * * * & (0.01) \\ & & & & & & & & & \\ \ldots & \ldots & \ldots & \ldots & 0.29 * * * & (0.03) & 0.38 * * * & (0.03) & 0.36 * * * & (0.03) \\ \ldots & \ldots & \ldots & \ldots & 0.06 * & (0.03) & -0.03 & (0.03) & -0.07 * & (0.03) \\ \ldots & \ldots & \ldots & \ldots & 0.17 * * * & (0.02) & 0.18 * * * & (0.02) & 0.18 * * * & (0.02) \\ \ldots & \ldots & \ldots & \ldots & 0.23 * * * & (0.02) & 0.20 * * * & (0.02) & 0.20 * * * & (0.02)\end{array}$

$\begin{array}{cccccccccc}\ldots & \ldots & \ldots & \ldots & \ldots & \ldots & -0.34 * * * & (0.02) & -0.33^{* * *} & (0.02) \\ \ldots & \ldots & \ldots & \ldots & \ldots & \ldots & \ldots & \ldots & -0.01 & (0.01)\end{array}$

$\begin{array}{llllllllll}\ldots & \ldots & \ldots & \ldots & \ldots & \ldots & \ldots & \ldots & -0.36^{* *} & (0.12) \\ \ldots & \ldots & \ldots & \ldots & \ldots & \ldots & \ldots & \ldots & -0.38^{* * *} & (0.05) \\ \ldots & \ldots & \ldots & \ldots & \ldots & \ldots & \ldots & \ldots & -0.03 & (0.09) \\ \ldots & \ldots & \ldots & \ldots & \ldots & \ldots & \ldots & \ldots & -0.43 & (0.22) \\ \ldots & \ldots & \ldots & \ldots & \ldots & \ldots & \ldots & \ldots & -0.35^{* * *} & (0.07) \\ \ldots & \ldots & \ldots & \ldots & \ldots & \ldots & \ldots & \ldots & -0.15 & (0.08) \\ \ldots & \ldots & \ldots & \ldots & \ldots & \ldots & \ldots & \ldots & -0.15 & (0.23) \\ \ldots & \ldots & \ldots & \ldots & \ldots & \ldots & \ldots & \ldots & 0.51^{* * *} & (0.12) \\ \ldots & \ldots & \ldots & \ldots & \ldots & \ldots & \ldots & \ldots & 0.48^{* *} & (0.18) \\ \ldots & \ldots & \ldots & \ldots & \ldots & \ldots & \ldots & \ldots & -0.04 & (0.09) \\ \ldots & \ldots & \ldots & \ldots & \ldots & \ldots & \ldots & \ldots & 0.16^{*} & (0.07)\end{array}$

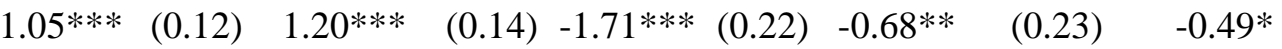

$(0.23)$

\begin{tabular}{ccccc}
23,426 & 23,426 & 23,426 & 23,426 & 23,426 \\
-13768 & -12722 & -12354 & -12151 & -12064 \\
-14364 & -14364 & -14364 & -14364 & -14364 \\
0.042 & 0.114 & 0.140 & 0.154 & 0.160 \\
\hline
\end{tabular}

Robust standard errors in parentheses

Note: $* * * p<0.001, * * \mathrm{p}<0.01 ; * \mathrm{p}<0.05$ 
Thus, in summary, even controlling for a wide range of other explanatory factors, the results here demonstrate that the significant relationships between these demographic variables and belief in anthropogenic climate change still holds in the expected directions. Of particular note is the fact that controlling for partisan and European identities does not reduce the gender coefficient, whereas controlling for one's values does.

\section{Identities:}

Turning the focus onto the relationships between identities and belief in anthropogenic climate change, as expected Green partisans display the highest levels of belief, with Liberal Democrat and Labour partisans also more likely to believe in the occurrence of climate change in comparison with those that do not have a partisan identity. Conservative partisans' belief is on par to those without a partisan identity once values have been accounted for, while UKIP partisans are the least likely to believe in climate change. Thus, the views of voters largely coincide with the positions of the parties themselves.

On EU Referendum identity, those with a Remain identity are more likely to believe in anthropogenic climate change than those with a Leave identity. However, those that do not possess a referendum identity are even less likely to believe. It should be kept in mind that this latter group make up a small percentage of the British population. Moreover, the stronger one's sense of Europeanness is the more likely one is to believe in anthropogenic climate change.

\section{Values and trust:}

When included in model 3, all of the values are significantly related to belief in anthropogenic climate change, though the magnitude of the libertarian-authoritarian scale is by far the weakest of all. Once trust in experts is added in model 4, the libertarianauthoritarian scale loses significance completely while left-right values and views on samesex marriage and traditional gender roles remain important. This suggests that equality values 
are more important than values regarding obedience, patriotism and respect for authority for predicting one's belief in anthropogenic climate change. It is also clear just how important a role trusting experts plays, given that those who would rather place their trust in the wisdom of ordinary people than the opinions of experts are far less likely to display such belief.

\section{Information}

Finally, I turn to the information variables. While stressing that this is a correlational relationship and that from these data one cannot make any claims on the causality of the relationship, the relationship between newspaper readership and climate change belief is very stark. Those who read newspapers that are more responsible in their communication of climate change - The Guardian and The Independent - are more likely to believe in anthropogenic climate change whereas readers of newspapers that have been criticised for the coverage they give to climate-sceptic voices - such as The Daily Mail, The Sun and The Express - are less likely to believe in anthropogenic climate change compared to those who do not read newspapers at all. There is however no direct relationship between self-reported political attention and climate change belief.

The results show support for the majority of hypotheses laid out. However, the hypotheses regarding interaction effects between political identities and political attention have not yet been tested. Given the elite cues noted in the literature, there are reasons to believe that the relationships between such identities and belief in climate change should be particularly strong among those who pay the greatest attention to politics.

I initially examine the interaction between partisanship and political attention by adding such an interaction to the fifth model contained in Table 1. To display these effects most clearly, I have plotted the coefficients from this model in Figure 2 below (see supplementary appendix Table A1 for the full results). Focusing on the interaction terms, one can see that Conservative and UKIP partisans that pay more attention to politics are less 
likely to believe in anthropogenic climate change whereas - though not statistically significant compared to those without a partisanship - Labour and SNP partisans who pay more attention to politics are more likely to believe in anthropogenic climate change,

Figure 2: Interaction of partisanship with political attention

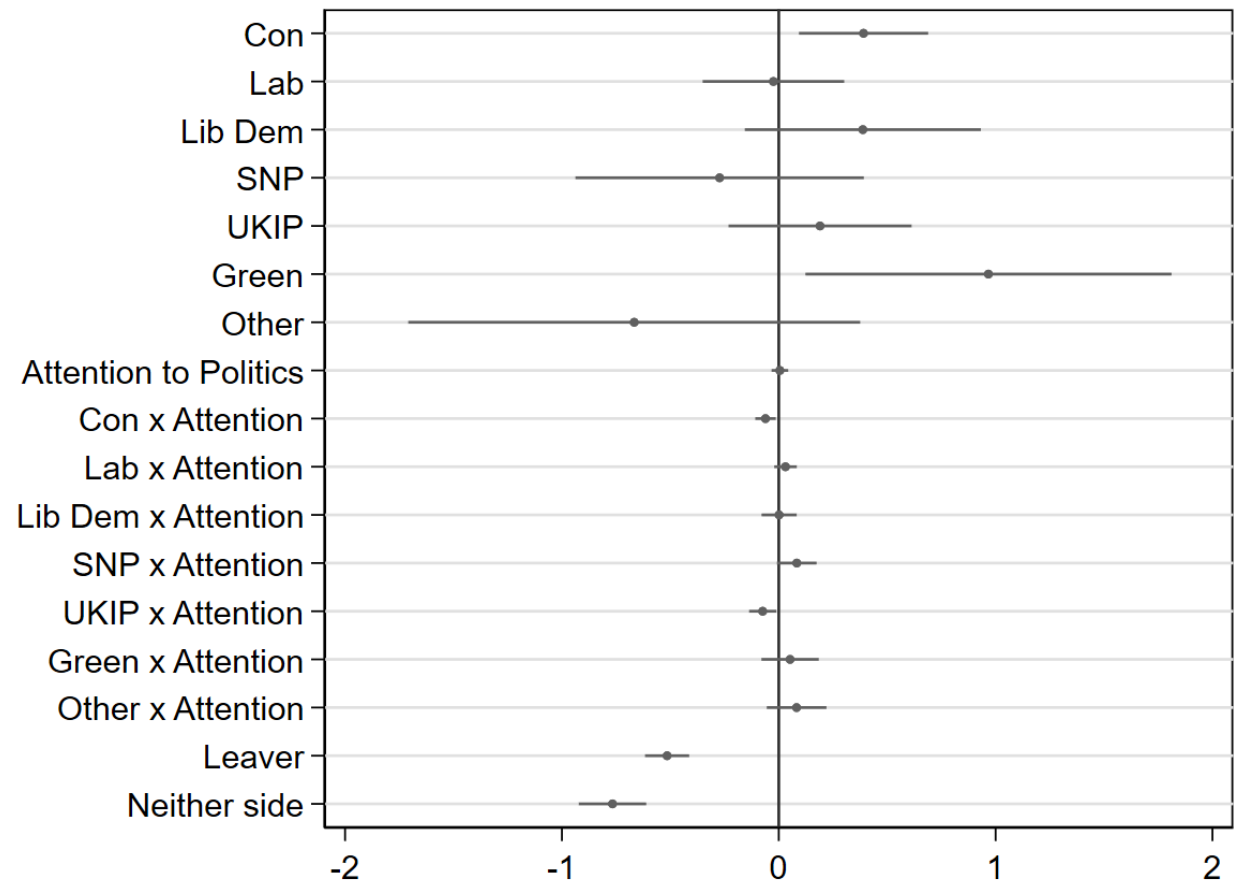

Note: "None" is the reference category for partisanship and "Remain" is the reference category for EU referendum identity. For each of the identity variables, "don't know" options are included but their coefficients are not displayed.

To determine the magnitude of these effects, in Figure 3 I plot the predicted probabilities of these interactions by each political party, keeping every other variable in the model at their mean values. This shows that Conservative and UKIP partisans who pay the least amount of attention to politics have, respectively, a $75 \%$ and $71 \%$ probability of believing in anthropogenic climate change, whereas those that pay the greatest attention to politics have a $63 \%$ and $55 \%$ probability. In contrast, Labour partisans who pay the least attention to politics have a $66 \%$ probability of believing in anthropogenic climate change, whereas those that pay the greatest attention to politics have a $74 \%$ probability. As we know that each of these parties were broadcasting diverging cues on the issue, this provides evidence of a coalescence between such cues and the beliefs of their supporters who are most likely to be exposed to them. With these party cues going in opposite directions to each other, 
they cancelled each other out in the non-interacted political attention term in Table 1 . And as those without a partisan identity show no difference in their belief in anthropogenic climate change at different levels of political attention, this provides further evidence that paying attention to politics by itself does not add any value to explaining climate change beliefs in the context of a uniform message not being sent out. No significant effect is found for Liberal Democrat or Green partisans which in itself is notable. For the Liberal Democrats, one factor in the lack of an interaction effect here could be that their profile was much reduced at this time given their reduction to single-digit parliamentary seats at the 2015 election and the associated loss of speaking time when losing their status as the third largest party. This in turn had knock-on effects for their public exposure. While there are some indications of positive effects of political attention for SNP partisans, those who feel close to them have relatively low proportions of low-attention partisans and thus the confidence intervals at these levels are too wide to make any definitive conclusions.

Figure 3: Predicted probabilities for belief in anthropogenic climate change by partisanship and political attention
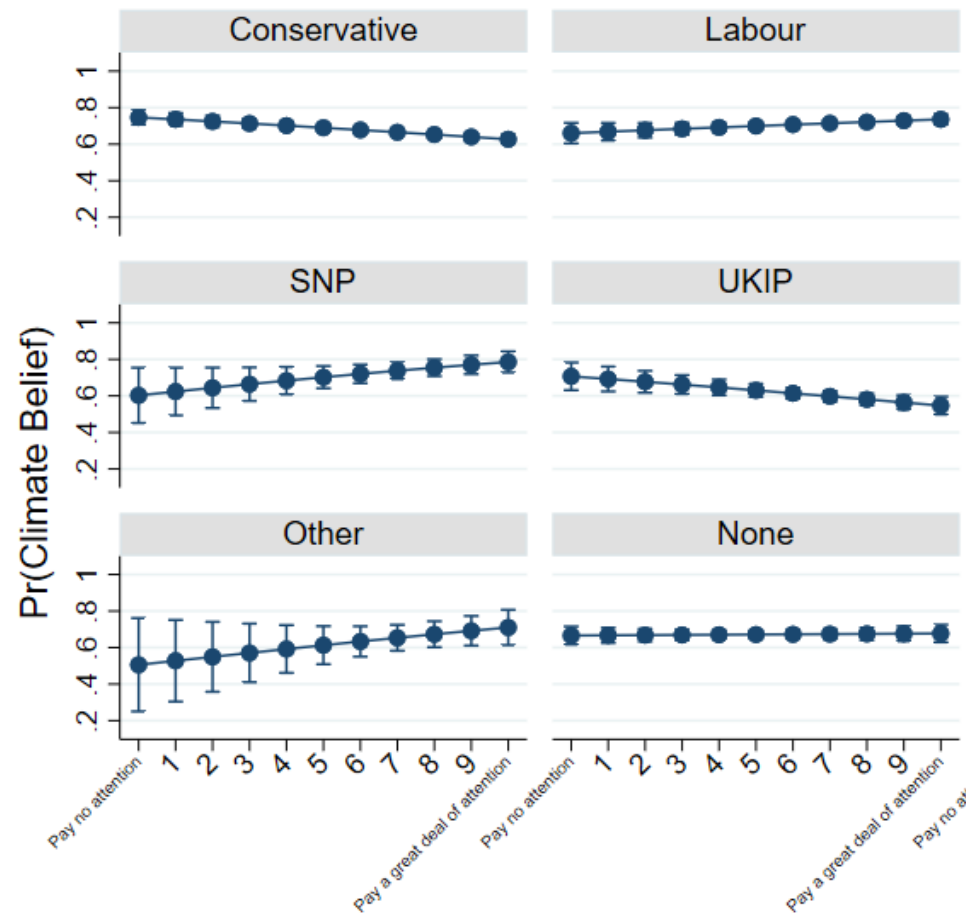

Attention to Politics
Labour
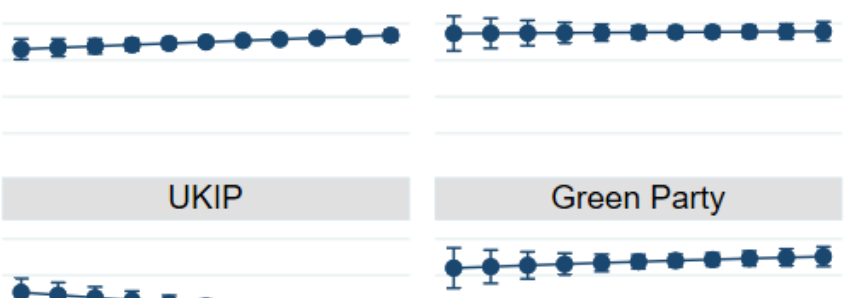
As well as partisan identities, I have also tested the effect of an interaction between the more recently formed EU referendum identities and reported political attention on belief in anthropogenic climate change. This interaction term has been added to the fifth model of Table 1, with the relevant coefficients plotted in Figure 4 (see supplementary appendix Table A1 for the full results). This shows a significant effect of the interaction. Those who identify as Leavers being less likely and Remainers more likely to believe in anthropogenic climate change if they pay greater attention to politics. While those who identify with neither side are less likely than both Leavers and Remainers to believe in climate change, the interaction between this group and the attention they pay to politics shows no significant difference.

Figure 4: Interaction of EU Referendum ID with political attention

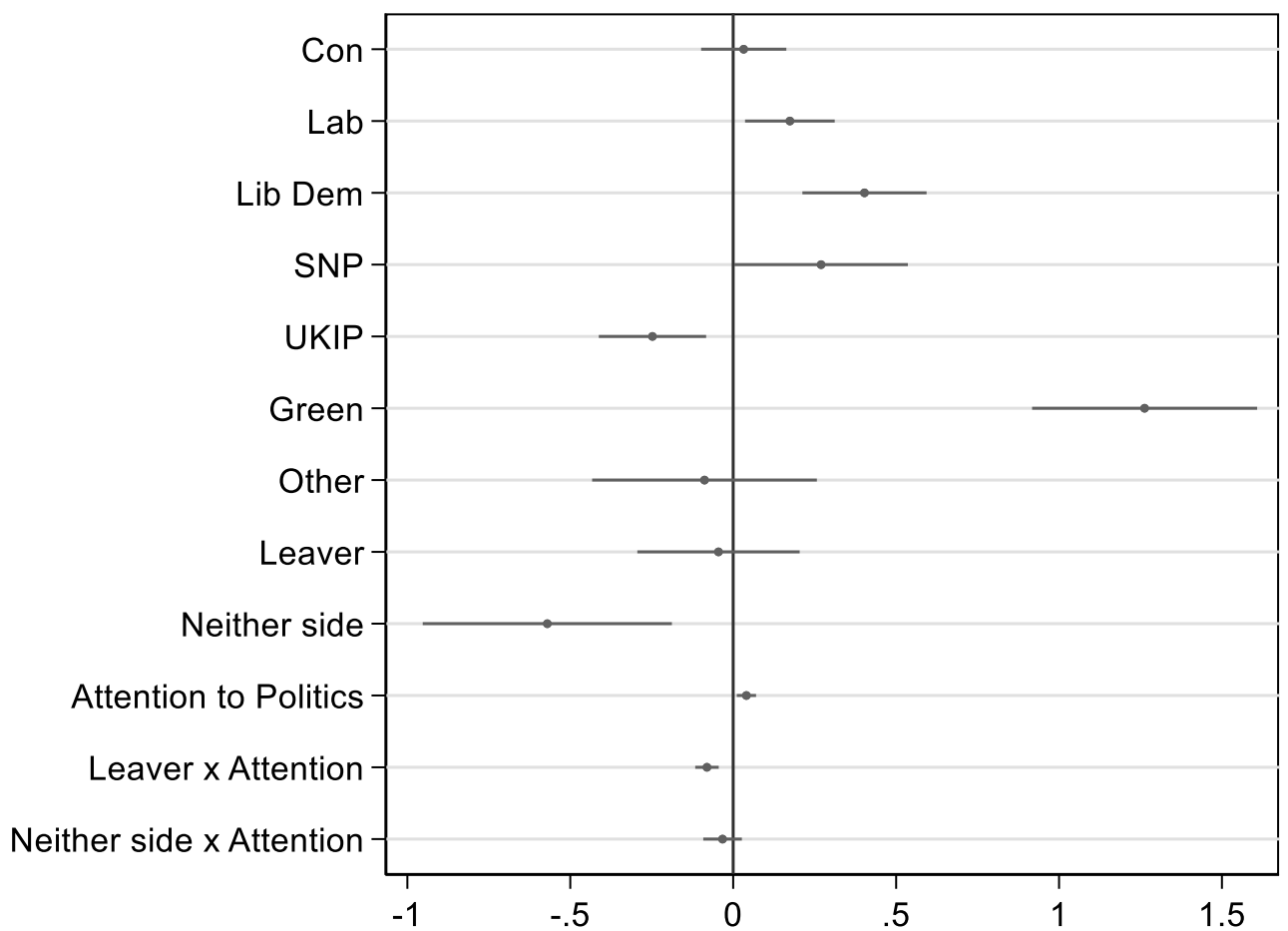

Note: "None" is the reference category for partisanship and "Remain" is the reference category for EU referendum identity. For each of the identity variables, "don't know" options are included but their coefficients are not displayed.

Figure 5 plots the predicted probabilities of these interaction terms, keeping every other variable in the model at their mean value. Among those who pay no attention to politics, there is no significant difference between such Leavers and Remainers in their 
climate change beliefs. With increasing political interest, Remainers display higher and Leavers lower belief in anthropogenic climate change and at the point of 3 on the $0-10$ scale the confidence intervals stop overlapping. Among those that pay the greatest attention to politics, Remainers have a $78 \%$ probability of believing in anthropogenic climate change whereas the probability for Leavers is just $61 \%$ - a 17 percentage point difference. The climate change belief of those that identify as neither a Remainer nor a Leaver does not vary with their attention to politics as was the case for those without a partisanship.

Figure 5: Predicted Probabilities for belief in anthropogenic climate change by EU Referendum ID and political attention

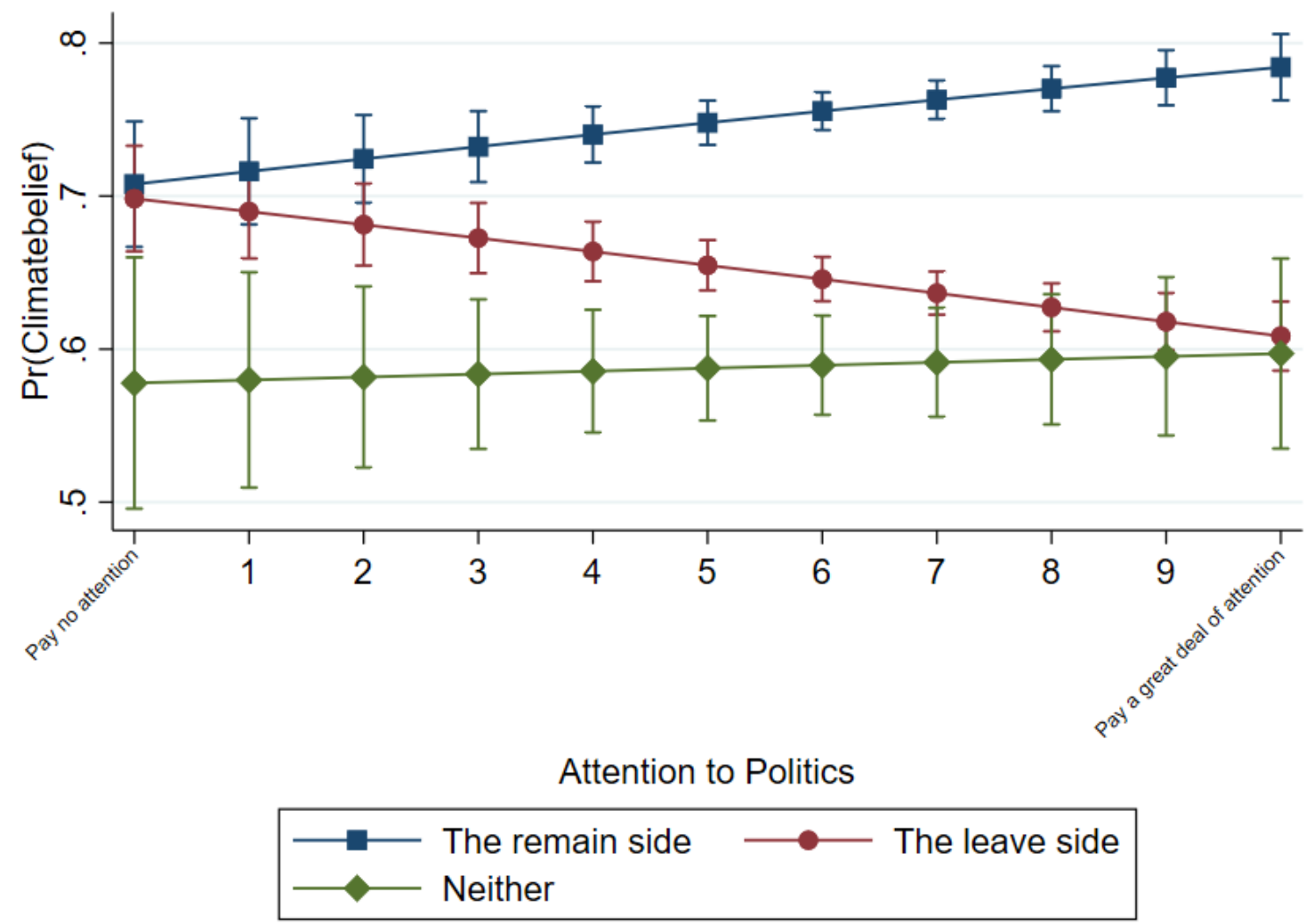

\section{Robustness}

For the analysis, I dichotomised the climate change belief variable into whether individuals stated that they believed that climate change was a result of human activity or that it was not. However, given that those who do not believe in climate change can be broken down further into sceptics (who agree that climate change is occurring, but not that humans are 
contributing to it), denialists (those who believe that climate change is not occurring) and those who just don't know, it is worthwhile carrying out multinomial logistic regressions to see whether this dichotomising affected the results. These tables can be found in supplementary appendix Table A2

For the demographics, there are a couple of notable differences. The most stark difference is that education levels do not distinguish between those that believe climate change is occurring due to human activity and climate sceptics, however with greater education levels people are far less likely to respond that they don't know. And while older individuals more likely to be climate sceptics, there is no age difference between those who believe climate change is occurring due to human activity and those who believe that climate change is not occurring at all. While females are less likely to be both climate sceptics and climate denialists than believers, they are more likely to respond 'don't know' than males. Household income does not distinguish between anthropogenic climate change believers and either climate sceptics or denialists, but those who don't know are less likely to be in a higher income bracket.

For the political identities variables, as their ideology would suggest UKIP partisans are far more likely to be climate change denialists, whereas Conservative and UKIP partisans are both more likely to be climate change sceptics. And the political identity interactions are present between those that believe in the scientific consensus and all other three categories with consistent significant differences seen between more informed Labour and Conservative partisans, as well as between Remainers and Leavers for climate sceptics and don't knows compared to the belief baseline, while the coefficient for denialists is in the expected direction though not significant. Finally, the conclusions for the relationship between political values, trust and newspaper readership are also similar. 
Another concern is that my sample size for analysis fell to under $80 \%$ of the original dataset by recoding don't know responses to missing in order to be able to construct my scales - with this being most notable for the left-right and liberal-authoritarian value scales and these missing responses may have biased my results. To address this and make use of the full sample, I carried out multiple imputation analysis using a multivariate normal distribution and both government approval and happiness that the UK voted to leave the EU as auxiliary variables due to their moderate to high correlations with variables that required imputation. The results are displayed in Tables A3 and A4 in the supplementary appendix. With an average RVI (Relative Increase in Variance) of .02 or below for all models, it indicates very small effects of the missing data on the variance of these estimates. The results are largely robust with a few key differences to the non-imputed analysis. The household income effect disappears once identities are controlled and the only regional differences are with the Northern regions who have significantly lower belief than those in London. The interpretation for everything else in the non-interacted models remains the same. For the imputed model with the political attention and partisan identities interaction, while the Conservative and UKIP interactions with political information are the same, the model shows that the reduced sample in the non-interacted model underestimated the magnitude of this positive interaction for Labour partisans as the coefficient is now significantly different from the baseline of those without any partisanship. There also appears to be a positive interaction affect for Green partisans. Finally, the interaction between political information and EU Referendum identities are robust.

\section{Conclusion}

This paper has demonstrated a number of important insights into belief in anthropogenic climate change in Britain. Firstly, the demographics of educational attainment, age, gender and region continue to exert effects on such belief even after controlling for various political 
identities and values. It also provides empirical evidence of a strong link with trusting the views of experts and believing in the scientific consensus.

The key finding is that the amount of attention an individual pays to politics moderates the association between political identities and anthropogenic climate change belief in Britain. Not only is this the case with partisan identities, but also with the more recently formed Brexit identities. Among Conservative/UKIP partisans and Leavers, greater political attention is associated with lower belief in the scientific consensus whereas for Labour partisans and Remainers it is associated with greater belief. This suggests that the different elite cues that such individuals would have been receiving - which became especially prominent following the passing of the 2008 Climate Change Act - may have influenced their beliefs.

While these effects are substantial, they have not yet reached the size seen in the US. Analysis using 2008 American National Election Study data shows that at the lowest levels of attention to political news the gap in predicted probabilities between liberals and conservatives believing that global warming is mostly manmade is just over 20 percentage points, though at the highest level of political attention this rises to approximately 60 percentage points. When political interest is used instead, there are no difference between liberals and conservatives who reply to the global warming statement at the lowest levels of political interest, but at the highest levels this also rises to a 60 percentage point difference (Tesler, 2018: 315/316). So while the direction of the effects found in Britain are the same, the magnitudes are far lower.

In saying that, it took a period of just a decade for these sizeable effects to materialise in the US and how it will evolve in Britain is unclear. On the one hand, the Conservative Party - in light of the increased public attention given to climate change in the aftermath of 
David Attenborough's Blue Planet documentary and the Extinction Rebellion protests - has recently shifted its rhetoric on climate change by presenting itself as a world leader in the area. Even if this shift since 2016 has been one of 'making unprecedented promises of action while they actively reverse the essential policies of mitigation in practice' (Innes, 2019), the cues from the party that cast doubt on humans' contribution to climate change appear to have lessened. On the other hand, climate change sceptics have not disappeared from the media with newspapers publishing pieces in the second half of 2019 including 'Climate change: fake news or global threat? This is the science' (Knapton, 2019) and 'The UN's 'woke' climate change propaganda is an insult to science' (Jacobs, 2019) in the Telegraph and 'Climate change bombshell: Humans are NOT to blame for global warming claims shock study' in the Express (Hans, 2019). Given the implications of believing humans have contributed towards climate change for being willing to support climate change policies, the combined effects of political identities and political attention on one's climate change beliefs in Britain should be followed closely in the coming years.

\section{References}

Anderson B, Böhmelt T and Ward H (2017) Public opinion and environmental policy output: A cross-national analysis of energy policies in Europe. Environmental Research Letters 12(11).

Bevington M (2018) Leave voters do not want a 'Global Britain'. Available at: https://ukandeu.ac.uk/leave-voters-do-not-want-a-global-britain/.

Bolsen T and Druckman JN (2018) Do partisanship and politicization undermine the impact of a scientific consensus message about climate change? Group Processes and Intergroup Relations 21(3): 389-402.

Brulle RJ and Roberts JT (2017) Climate Misinformation Campaigns and Public Sociology. Contexts 16(1): 78-79. DOI: 10.1177/1536504217696081.

Brulle RJ, Carmichael J and Jenkins JC (2012) Shifting public opinion on climate change: an empirical assessment of factors influencing concern over climate change in the U.S., 2002-2010. Climatic Change 114(2): 169-188.

Caney S (2010) Human Rights and Global Climate Change. In: Pierik R and Werner W (eds) Cosmopolitanism in Context: Perspectives from International Law and Political Theory. Cambridge: Cambridge University Press, pp. 19-44. 
Capstick S, Demski CC, Sposato RG, et al. (2015) Public perception of climate change in Britain following the winter 2013/2014 flooding. Understanding Risk Research Group Working Paper 15-01.

Carter N (2009) Vote blue, go green? cameron's conservatives and the environment. Political Quarterly 80(2): 233-242.

Carter N (2014) The politics of climate change in the UK. Wiley Interdisciplinary Reviews: Climate Change 5(3): 423-433. DOI: 10.1002/wcc.274.

Carter N and Clements B (2015) From 'Greenest Government Ever' to 'Get Rid of the Green Crap': David Cameron, the Conservatives and the Environment. British Politics 10(2): 204-225.

Clements B (2012) Exploring public opinion on the issue of climate change in Britain. British Politics 7(2): 183-202.

Committee on Climate Change (2019) Reducing UK emissions: 2019 Progress Report to Parliament. Available at: https://www.theccc.org.uk/publication/reducing-uk-emissions2019-progress-report-to-parliament/.

ComRes (2017) Energy and Climate Change Survey. Available at: https://www.comresglobal.com/wp-content/uploads/2017/02/ECIU-Energy-andClimate-Change-Survey-Feb-2017.pdf.

Devine-Wright P, Price J and Leviston Z (2015) My country or my planet? Exploring the influence of multiple place attachments and ideological beliefs upon climate change attitudes and opinions. Global Environmental Change 30: 68-79.

Dunlap RE, McCright AM and Yarosh JH (2016) The Political Divide on Climate Change: Partisan Polarization Widens in the U.S. Environment: Science and Policy for Sustainable Development 58(5): 4-23.

Fairbrother M (2017) Environmental attitudes and the politics of distrust. Sociology Compass 11(5): 1-10.

Fieldhouse E, Green J, Evans G, et al. (2016) British Election Study Internet Panel Wave 10 Version 0.8/0.9. DOI: DOI: 10.15127/1.293723.

Fisher SD (2019) Is Public Support for Climate Change Mitigation in Danger of Melting Away? Deltapoll. Available at: http://www.deltapoll.co.uk/breaking-the-grip-2-2-2.

Fisher SD, Fitzgerald R and Poortinga W (2018) Climate change: Social divisions in beliefs and behaviour. In: Phillips D, Curtice J, Phillips M, et al. (eds) British Social Attitudes: The 35th Report. London, pp. 146-171.

Flanagan SC and Lee A-R (2003) The New Politics, Culture Wars, and The AuthoritarianLibertarian Value Change in Advanced Industrial Democracies. Comparative Political Studies 36(3): 235-270.

Flynn DJ, Nyhan B and Reifler J (2017) The Nature and Origins of Misperceptions: Understanding False and Unsupported Beliefs About Politics. Political Psychology 38(S1): 127-50.

Hans G (2019) Climate change bombshell: Humans are NOT to blame for global warming claims shock study. Express, 23 July. Available at: 
https://www.express.co.uk/news/science/1156605/Climate-change-news-globalwarming-hoax-fake-proof-study-research-science-sun-space.

Hmielowski JD, Feldman L, Myers T a, et al. (2013) An attack on science? Media use, trust in scientists, and perceptions of global warming. Public understanding of science 23(7): $866-883$.

Hobolt SB and Tilley J (2019) The Brexit Identity Divide. In: Brexit and Public Opinion 2019. The UK in a Changing Europe, pp. 20-22.

Hobolt SB, Leeper TJ and Tilley J (2020) Divided by the vote: affective polarization in the wake of the Brexit Referendum. British Journal of Political Science. Available at: http://eprints.lse.ac.uk/103485/1/Divided_by_the_vote.pdf.

House of Commons Science and Technology Committee (2014) Communicating Climate Science: Eight Report of Sessions 2013-2014. London.

Huber RA (2020) The role of populist attitudes in explaining climate change skepticism and support for environmental protection. Environmental Politics. DOI: 10.1080/09644016.2019.1708186.

Innes A (2019) Conservative government climate policy is more dangerous than one of open denial. Available at: https://blogs.lse.ac.uk/politicsandpolicy/government-climatepolicy/.

Ipsos MORI (2020) Ipsos-MORI Issues Index December 2019. Available at: https://www.ipsos.com/sites/default/files/ct/news/documents/202001/tables_december_2019_issues_index_public.pdf.

Jacobs S (2019) The UN's 'woke' climate change propaganda is an insult to science. The Telegraph, 3 December. Available at: https://www.telegraph.co.uk/news/2019/12/03/uns-woke-climate-change-propagandainsult-science/.

Jasny L, Waggle J and Fisher DR (2015) An empirical examination of echo chambers in US climate policy networks. Nature Climate Change 5(August): 783-786.

Jost JT and Hunyady O (2005) Antecedents and consequences of system-justifying ideologies. Current Directions in Psychological Science 14(5): 260-265.

Jost JT, Glaser J, Kruglanski AW, et al. (2003) Political Conservatism as Motivated Social Cognition. Psychological Bulletin 129(3): 339-375.

Kenny J (2018) The role of economic perceptions in influencing views on climate change: an experimental analysis with British respondents. Climate Policy 18(5): 581-592.

Kenny J (2020) Are Environment Versus Economy Trade-Off Questions More About Environmental or Economic Attitudes? International Journal of Public Opinion Research. DOI: 10.1093/ijpor/edaa003.

Knapton S (2019) Climate change: fake news or global threat? This is the science. The Telegraph, 15 October. Available at: https://www.telegraph.co.uk/science/2019/10/15/climate-change-fake-news-globalthreat-science/.

Knutsen O (2017) Social Structure, Value Orientation and Party Choice in Western Europe. 
Cham: Palgrave Macmillan.

Krosnick JA, Holbrook AL, Lowe L, et al. (2006) The Origins and Consequences of democratic citizens' Policy Agendas: A Study of Popular Concern about Global Warming. Climatic Change 77(1): 7-43.

Leiserowitz A, Maibach E, Roser-Renouf C, et al. (2013) Climategate, Public Opinion, and the Loss of Trust. American Behavioral Scientist 57(6): 818-837.

Lockwood M (2013) The political sustainability of climate policy: The case of the UK Climate Change Act. Global Environmental Change 23: 1333-1348.

Lockwood M (2018) Right-wing populism and the climate change agenda: exploring the linkages. Environmental Politics 27(4): 712-732.

Martell L (2017) The Future for Cosmopolitan Social Democracy. DOI: 10.31235/osf.io/wykxb.

McCright AM and Dunlap RE (2010) Anti-reflexivity: The American conservative movement's success in undermining climate science and policy. Theory, Culture and Society 27(2-3): 100-133.

McCright AM and Dunlap RE (2011) The Politicization Of Climate Change And Polarization In The American Public's Views Of Global Warming, 2001-2010. Sociological Quarterly 52(2): 155-194.

Merkley E and Stecula DA (2018) Party Elites or Manufactured Doubt? The Informational Context of Climate Change Polarization. Science Communication 40(2): 258-78.

Painter J and Gavin NT (2016) Climate Skepticism in British Newspapers, 2007-2011. Environmental Communication 10(4): 432-452.

Pearce R (2015) Regional attitudes to climate change across the UK. Available at: https://www.carbonbrief.org/analysis-regional-attitudes-to-climate-change-across-theuk.

Pidgeon N and Fischhoff B (2011) The role of social and decision sciences in communicating uncertain climate risks. Nature Climate Change (1): 35-41.

Plumer B and Popovich N (2018) The World Still Isn't Meeting Its Cliamte Goals. Available at: https://www.nytimes.com/interactive/2018/12/07/climate/world-emissions-parisgoals-not-on-track.html.

Poortinga W, Spence A, Whitmarsh L, et al. (2011) Uncertain climate: An investigation into public scepticism about anthropogenic climate change. Global Environmental Change 21(3): 1015-1024.

Poortinga W, Whitmarsh L, Steg L, et al. (2019) Climate change perceptions and their individual-level determinants: A cross-European analysis. Global Environmental Change 55. Pergamon: 25-35.

Reed M (2016) 'This loopy idea' an analysis of UKIP's social media discourse in relation to rurality and climate change. Space and Polity 20(2): 226-241.

Remnick D (2015) 2005-2015. The New Yorker: 90th Anniversary Edition - February 23 \& March 22015. 
Santos J and Feygina I (2017) Responding to Climate Change Skepticism and the Ideological Divide. Michigan Journal of Sustainability 5(1): 5-23.

Stocker TF, Qin D, Plattner G-K, et al. (2013) Climate Change 2013 - The Physical Science Basis. Intergovernmental Panel on Climate Change. Cambridge: Cambridge University Press.

Swales K (2016) Understanding the Leave Vote. London: National Centre for Social Research.

Tesler M (2018) Elite Domination of Public Doubts About Climate Change (Not Evolution). Political Communication 35(2): 306-326.

United Nations Environment Programme (2017) The Emissions Gap Report 2017. Available at: https://wedocs.unep.org/bitstream/handle/20.500.11822/22070/EGR_2017.pdf.

Van Der Linden SL, Leiserowitz AA, Feinberg GD, et al. (2015) The scientific consensus on climate change as a gateway belief: Experimental evidence. PLoS ONE.

Whitmarsh L (2011) Scepticism and uncertainty about climate change: Dimensions, determinants and change over time. Global Environmental Change 21(2): 690-700.

YouGov (2015) YouGov Tracker - Most Important Issues May 2015. Available at: https://d25d2506sfb94s.cloudfront.net/cumulus_uploads/document/0g3zhv6y3h/YGArchives-Pol-Trackers-Issues(2)-Most-important-issues-260515.pdf.

YouGov (2020) YouGov Tracker - Most Important Issues February 2020. Available at: https://d25d2506sfb94s.cloudfront.net/cumulus_uploads/document/s7d4bpxjcw/YG Trackers - Top Issues_W.pdf. 